\title{
Does It Pay to Be Sustainable? Evidence from European Banks
}

\author{
Candida Bussoli ${ }^{1}$, Danilo Conte ${ }^{1}$, Graziana Letorri ${ }^{1} \&$ Marco Barone $^{1}$ \\ ${ }^{1}$ Department of Economics and Management, LUM Jean Monnet University, Italy. \\ Correspondence: Danilo Conte, Department of Economics and Management, LUM Jean Monnet University, S.S. \\ 100 km 18, 70010 Casamassima (BA), Italy. E-mail: conte@lum.it
}

Received: November 2, 2018

Accepted: December 10, 2018

Online Published: December 19, 2018

doi:10.5539/ijbm.v14n1p128

URL: https://doi.org/10.5539/ijbm.v14n1p128

\begin{abstract}
This paper aims to explore the relationship between the economic, environmental, social, and corporate governance component of Corporate Social Performance (CSP) and the Corporate Financial Performance (CFP) in the European banking sector. The empirical analyses, based on panel data, are performed on a sample of 70 listed European banks (EU28) over the period 2011-2015. The main results show a significant and positive relationship between the aggregated CSP measure and the average profitability of banks' assets and market capitalization. Furthermore, the social component positively affects the average return on assets and equity; the economic component is positively associated with the performance of prospective profitability and market capitalization; finally, the environmental component is positively associated with the ROAA. Sustainable banks, in line with the stakeholder Theory, through ethical and social policies, might increase their financial and economic performance.
\end{abstract}

Keywords: corporate social performance, sustainable banking, financial performance, stakeholders theory

\section{Introduction}

In the decades, the concept of Corporate Social Responsibility (CSR) has gone from a narrow notion to a complex and multifaceted, including a variety of definitions (Aguinis \& Glavas, 2012). Indeed CSR may be considered as a managerial tool, applied on a voluntary basis, which incorporates ethical, environmental and social values and which directs the management of companies towards behaviors, processes and strategies that lead to the simultaneous satisfaction of stakeholders (Murray \& Dainty, 2013). The present work deals with the issue of corporate social responsibility focusing on the banking system which, in addition to playing a key role in economic growth (Levine, 2004), is strongly sensitive to the need to manage the issue of social responsibility in a competitive key.

During the recent financial crisis, the banks suffered economic and financial damage but, above all, reputational damage and the CSR policies can represent the means by which they can reacquire and increase intangible resources and legitimize economic performance (Birindelli, Ferretti, Intonti, \& Iannuzzi, 2015).

The literature on non-financial companies' CSR focuses on the relationship between Corporate Social Performance (CSP) and Corporate Financial Performance (CFP); the results are not unique, but they represent, mainly, a positive relationship between CSP and CFP. (Freeman, 1984; Griffin \& Mahon, 1997; Salomon \& Salomon, 2006; Oh, Chang, \& Martynov, 2011; Lev, Petrovits \& Radhakrishnan, 2010; Surroca, Tribó, \& Waddock, 2010; Orlitzky, Schmidt \& Rynes, 2003; Wang, Dou \& Jia, 2016).

The reasons for the heterogeneity of the results are both theoretical and operational and essentially due to the fact that CSR is a multidimensional concept (Wartick \& Cochran, 1985; Wood, 1991; Griffin \& Mahon, 1997) that embodies a wide range of business behaviors, so it is difficult to obtain a measure able to grasp all the components (Waddock \& Graves, 1997).

Also in the financial sector empirical studies are inconclusive and very limited (Van Beurden \& Gössling, 2008; Wu \& Shen, 2013). The main contributions confirm the discordant results obtained in the non-financial sector: part of the literature observes a positive relationship (Simpson \& Koher, 2002; Callado-Muñoz \& Utrero-González, 2011; Wu \& Shen, 2013; Forcadell \& Aracil, 2017); another part a negative relationship (Scholtens \& Dam, 2007; Wu \& Shen, 2013) or no relationship (Chih, Chih, \& Chen, 2010; Soana, 2011; Wu \& Shen, 2013). 
The present work is part of the line of studies that find a positive relationship, testing the theoretical assumptions of the Stakeholder Theory.

The sample examined consists of 70 listed European banks (EU28), observed over a period between 2011 and 2015, characterized by the sovereign debt crisis that had a major impact on the European credit system.

The work contributes to the reference literature trying to capture the multidimensional aspect of the CSP. The CSP variable is measured by the Equal Weighted rating, which is the result of the weighting of the company's performance based on four components: economic, environmental, social, and corporate governance. Therefore, five research hypotheses have been formulated, in order to test the relationship between CSP and CFP, and then the relationship between the individual components of the CSP and the CFP.

The main results show a significant and positive relationship between the aggregated CSP measure and the average profitability of banks' assets and their market capitalization, confirming the Good Management View. Furthermore, the social component positively impacts the average return on assets and equity; the economic component is positively associated with the performance of prospective profitability and market capitalization; finally, the environmental component is positively associated with the ROAA.

The work is structured as follows: the second paragraph provides the literature review and the research hypotheses. The third paragraph illustrates the methodology, the variables used in the study and the sample. Finally, fourth section describes the primary results and the final section provides brief conclusive assessments.

\section{Literature Review}

The social implications deriving from the CSR programs have been the subject of numerous studies (Berle, 1930; Bowen, 1953; Davis, 1960; CED, 1971; Frederick, 1986, 1994; Carroll, 1979; Porter \& Kramer, 2006) but the interest on these topics only recently has become more marked, shifting the debate from ideology to reality (Maon, Lindgreen, \& Swaen, 2010), generating an autonomous discipline characterized by a variety of theoretical orientations, methodological approaches and terminologies (Garriga \& Melè, 2004).

CSR has been studied by several managerial perspectives including cost perspective, agency theory, instrumental stakeholder theory, resource-based view (RBV), reputation theory (Friedman, 1970; Freeman, 1984; Godfrey, Merrill, \& Hansen, 2009; Muller \& Kraussl, 2011).

It follows that this terminology does not match a single definition. We often talk about business ethics (Frederick, 1986), corporate citizenship (Carroll, 1998) and other related topics, such as sustainable development (Moon, 2007; Weber, Diaz \& Schwegler, 2014), but the common idea is based on the needs of stakeholders, which go beyond compliance with the legal requirements, identifying practices and behaviors that a company adopts on a voluntary basis in the conviction of obtaining results that can bring benefits and advantages to the firm itself and to the context in which it operates (Murray \& Dainty, 2013).

Numerous studies have examined the impact of Corporate Social Performance on Corporate Financial Performance, since CSR requires an economic justification; indeed, without quantifiable benefits for companies these practices could be excessively burdensome compared to the limited financial resources of companies (Wang, Choi \& Li, 2008).

The existing empirical literature has mostly focused on the nature of the CSP-CFP relationship (Aupperle, Carroll \& Hatfield, 1985; Ullmann, 1985; Orlitzky et al., 2003) wishing to test the existence of a statistically significant relationship between the two measures, but to date the link is far from clear (Ullmann, 1985; Waddock \& Graves, 1997; Margolis \& Walsh, 2003; Wang et al., 2016) because of the inconsistent results.

Some studies state that the adoption of CSR practices increases the performance of companies, as claimed by the Stakeholder theory (Freeman, 1984; Lev et al., 2010; Surroca et al., 2010) that suggests that the value of companies depends on the cost of explicit requests from shareholders, but also on implicit requests from other stakeholders (McGuire, Sundgren \& Schneeweis, 1988). The needs of different types of subjects lead to better coordination of the entrepreneurial activity, which leads to the satisfaction of the various stakeholders, thereby improving the economic and financial performance of the company (Freeman, 1984; Porter \& Van der Linde, 1995).

Other empirical analyses state that the relationship between CSP and CFP is negative, in line with the Shareholder theory (Aupperle et al., 1985), according to which the company's sole social responsibility is to make profits and increase the economic value in favour of shareholders (Friedman, 1970).

Part of the literature supports the absence of the relationship (Alexander \& Buchholz, 1978; Aupperle et al., 1985; Freedman \& Jaggi, 1986). Others argue that the relationship is not linear, not constant over time and can take the 
form of "U" or "inverted U" (Barnett \& Salomon, 2006).

Finally, in order to study the CSP-CFP binding, some scholars have carried out meta-analyzes (Margolis \& Walsh, 2003; Orlitzky \& Benjamin, 2001; Orlitzky et al., 2003) showing that in most empirical studies the relationship is positive and establishing that, in the long run, the benefits prevail over costs.

In the banking sector, the focus on Corporate Social Responsibility developed late compared to other sectors, but with a growing interest from associations, institutions and academics (GRI, 2008; EBF, 2008; Viganò \& Nicolai, 2009; Yen, 2014).

The financial system considers the need to manage the issue of social responsibility in a competitive key, so as to underline the fundamental role it plays in economic development (Levine, 2004; Shen \& Lee, 2006; Beck, Demirgüç-Kunt \& Levine, 2010) and the market (Matei \& Voica, 2013; Fatma, Rahman \& Khan, 2014).

In recent decades, the banks' activity has diverged in part from the financing of the real economy, increasingly focusing on investment activities in complex and structured financial instruments, seeking higher profit margins. These choices led to the adoption of excessive risk. The direct consequence was not only on the economic-financial equilibrium of the banks but also on their reputation, undermining the fiduciary relationship between the bank and the customers.

In this perspective, CSR is seen as a tool through which banks can recover and reconnect with the market and regain greater legitimacy, with the aim of restoring their image and credibility (Hsu, 2012; Newig et al., 2013), to increase trust and reputation (Lourenço, Callen, Branco, \& Curto, 2014), as well as the transparency deriving from it.

Indeed, a healthy banking system is the key to sustainable prosperity, (King \& Levine, 1993) and the security and soundness of these institutions can create different external benefits for society (Wu \& Shen, 2013).

Banks can focus on internal environmental management (Jeucken \& Bouma, 1999) to reduce the direct environmental impact, and this can improve their reputation (Babiak \& Trendafilova, 2011), but the main link between the financial sector and sustainable development is an indirect link (Schmidheiny \& Zorraquin, 1996; Scholtens, 2008); through the intermediation process, banks can take on the role of propelling the economy and sustainable development, causing significant repercussions on social dynamics and banks themselves.

Sustainable development needs the support of the financial intermediaries so that the flow of capital, in the phase of allocation of resources, can preferentially be directed to projects that enhance the social component (Scholtens, 2008).

These practices do not end with social marketing operations, drafting social reports or ethical codes, but must be a strategic management method, through full involvement in sustainability programs (Jo \& Na, 2012), implemented in a multi-stakeholder perspective, i.e. creating a continuous dialogue with all interlocutors (Manetti, 2011).

Compared to other sectors, a key feature of the banking sector is that it refers to more diversified and complex groups of stakeholders (Dorasamy, 2013; Ofori, S-Darko \& Nyuur, 2014) and this translates into considerable information asymmetry. Such asymmetries are reduced through feedbacks to the community, more frequently performed than in other sectors (Wu \& Shen, 2013). Banks are aware of using public resources and this awareness explains why many banks enter a section on CSR in their annual reports to explain their contribution to society (Wu \& Shen, 2013). Birindelli and Tarabella (2001) show that over the years, in the financial sector, there has been a significant increase in the dissemination of contributions in socially responsible projects (Hossain \& Reaz, 2007) through websites (Douglas, Doris \& Johnson, 2004) or social reports (Branco \& Rodrigues, 2006). At the same time, there is an increase in the adoption of standard guidelines and the diversification of the information that mainly focus on human resources, the community (Clarke \& Gibson-Sweet, 1999; Branco \& Rodrigues, 2006; Stubbs \& Cocklin, 2008), products and services offered (Hamid, 2004) the environment (Clarke \& Gibson-Sweet, 1999; Douglas et al., 2004; Hamid 2004) or recycling (Viganò \& Nicolai, 2009). Greenwood and Jovanovic (1990) argue that intermediaries who achieve better results are successful companies able to achieve an efficient allocation of capital.

It follows that engaging in CSR policies leads to important implications in the banking sector (Forecadell \& Aracil, 2017), determining benefits for banks (Fombrun \& Shanley, 1990; Herremans, Akathaporn \& McInnes, 1993; Podolny, 1993; Landon \& Smith, 1997; Polychronidou, Ioannidou, Kipouros, Tsourgiannis \& Simet, 2014).

No adequate framework exists to evaluate and quantify the efforts of the socially responsible programs in the 
banking system (Scholtens, 2009). Empirical studies are inconclusive and also very limited (Wu \& Shen, 2013), reaffirming the results obtained in for the non-financial sector: some authors affirm the existence of a positive relationship between CSR and performance of financial companies (Simpson \& Koher, 2002; Callado-Muñoz \& Utrero-González, 2011; Saxena \& Kholi, 2012; Weshah, Dahiyat, Awwad \& Hajjat, 2012; Wu \& Shen, 2013; Iqbal, Ahmad \& Kanwal, 2013; Ahamed, Almsafir \& Al-Smadi, 2014; Forcadell \& Aracil, 2017; Carnevale \& Mazzuca, 2014), others a negative relationship (Scholtens \& Dam, 2007; Wu \& Shen, 2013) or no relationship (Chih et al., 2010; Soana, 2011; Wu \& Shen, 2013).

The researchers tried to identify the motivations, both theoretical and operational, that led to the failure to achieve a univocal result and these motivations can be traced to the following aspects: mismatching of stakeholders (Wood \& Jones, 1995); theoretical deficiencies and inadequate definitions of key terms (Ullmann, 1985); determinants and boundaries of the CSR, (Brammer \& Millington, 2008; Barnett, 2007); use of multisector samples; financial performance measurement problems; social performance measurement problems (Griffin \& Mahon, 1997), since CSR is a multidimensional construct (Wartick \& Cochran, 1985). Therefore, for the reasons listed, it is difficult to identify and measure a wide range of social behaviors.

\subsection{Research Hypothesis}

In this study, the Equal Weighted Rating provided by Thomson Reuters is used as a CSP variable, which contains various components that capture the multidimensional aspect of CSR: corporate governance, social, environmental and economic. The use of this measure is supported by the literature (Semenova \& Hassel, 2015).

The governance component is measured according to five categories: functions of the board of directors, the structure of the board of directors, compensation policy, shareholder policy, vision, and strategy. The focus on the governance component is motivated by its role in influencing the decision to invest in socially responsible companies (Walls, Berrone \& Phan, 2012). The implications of good governance are believed to help companies avoid adverse situations, create economic value for shareholders, improve financial results (Gompers, Ishii \& Metrick, 2009), as well as take into account the interests of a wide range of interlocutors, as well as the communities in which they operate. In fact, investors consider the social behavior of companies in their investment decisions (Simpson \& Kohers, 2002; Aguilera, Williams, Conley \& Rupp, 2006; Matten, 2006); therefore, they require that the boards of directors and managers engage in CSR (Scholtens, 2008; Kolk \& Pinkse, 2010).

The social component includes seven categories: community, diversity, quality of employment, health and safety, human rights, product or service responsibility, and training-development. This component could be considered as a reflection of reputation. Financial intermediaries tend to manage reputation in a competitive key, being a strategic resource (Branco \& Rodrigues, 2006) for service companies with a predominantly intangible offer, as it provides a basis for a strategy of differentiation (Van Heerden \& Puth, 1995; Chen \& Chen, 2009; Bravo, Montaner \& Pina, 2010; Hsu, 2012; Pérez \& del Bosque, 2013; Walsh, Bartikowski \& Beatty, 2014; Brammer, Agarwal, Taffler \& Brown, 2015) allowing competitive advantages and obstacles to imitation (McWilliams \& Siegel, 2001). In this way, reputation links sustainability and performance (Orlitzky \& Swanson, 2012). In the theoretical model of Chemmanur and Fulghieri (1994), banks with high reputation show a better ability to assess creditworthiness than banks with low reputation. Bushman and Wittenberg-Moerman (2012) document that high reputation banks are associated with higher profitability and credit quality of borrowers in the three years following the granting of the loan. Some studies claim that banking reputation certifies the borrower's quality because borrowers have abnormal positive equity returns when loans are issued by reputable banks (Billet, Flannery \& Garfinkel, 1995; Ross, 2010).

The environmental component includes three categories: reduction of emissions, product innovation and reduced use of resources. The financial sector can influence the environmental and sustainable impacts of funded projects or borrowers (Thompson \& Cowton, 2004; Egede \& Lee, 2007; Baranes, 2009; Scheire \& De Maertelaere, 2009). The environmental issues affecting a bank are related to the direct and indirect environmental concerns. Through the indirect link, the bank has environmental responsibility and should finance sustainable companies (Idowu \& Filho, 2009; Weber, 2012). Therefore, the banks focused on managing the environmental risks (Thompson \& Cowton, 2004; Egede \& Lee, 2007; Baranes, 2009; Scheire \& De Maertelaere, 2009), integrating the assessment of the sustainability risks in the management processes of credit risks (Hugenschmidt, Kermode, Schumacher \& Janssen, 1999; Thompson \& Cowton, 2004; Weber, 2005; Evangelinos, Skouloudis, Nikolaou \& Filho, 2009). Environmental risks and environmental regulations have a significant influence on the credit risk of a bank's portfolio (Bacow, 1998; Labatt \& White, 2002; Weber, Fenchel \& Scholz, 2008).

The economic component includes customer loyalty, economic results and satisfaction of shareholders. The 
evaluation of the company cannot be limited only to economic and financial aspects (Humphrey, Lee \& Shen, 2012; Revathy, 2012; Sakarya, Bodur, Yildirim-Öktem \& Selekler-Göksen, 2012). Organizations should pursue economic, social and environmental objectives (Elkington, 1997), integrating social and environmental aspects into their strategic plan. It is a holistic approach to CSR according to which the enterprise is considered an open system (Boulding, 1956), as it is involved in a series of relationships with numerous subjects that are able to influence operation and performance.

Moreover, banks consider their fundamental ethical responsibility not only as a prerequisite for profitable business management but also in terms of economic and social justice (Milanzi, 1997; Smurthwaite, 2014). Lantos (2001) argues that strategic CSR aligns strategic business objectives with the well-being of the society. In this regard, banks can identify activities that may generate benefit for business and society through long-term investments, thereby promoting profitable results for both parties. Through the reconciliation of social and economic benefits, the gain can be in the form of new business opportunities, as well as an increase in goodwill and philanthropic practice for the benefit of all stakeholders; according to Bhattacharya and Sen (2004) and Jamali (2007), this offers a perspective of greater credibility, added value and positive internal results. Therefore, it is essential that banks in building their identity and role in society not only care about their own interests and legal requirements, but also about the expectations of all stakeholders (Dorasamy, 2013), which may include consumer awareness, positive attitudes towards the company, consumer welfare (Bhattacharya \& Sen, 2004), in order to expand the customer base and win the trust of citizens (Achua, 2012).

This work is part of the "Stakeholders Theory" by Freeman (1984), which provides that the company can increase its financial resources by improving relations with the company's primary stakeholders.

This positive relationship between social and financial performance in the banking sector has been identified in most of the previous studies (Simpson \& Kohers, 2002; Wu \& Shen, 2013; Forcadell \& Aracil, 2017; Weber, 2017; Shen, Wu, Chen \& Fang, 2016; Esteban-Sanchez, la Cuesta-Gonzalez \& Paredes-Gazquez, 2017; Bussoli \& Conte, 2018).

Therefore, in line with the reference literature it is possible to formulate the following research hypotheses:

HY1: Banks' Corporate Social Performance positively influences Corporate Financial Performance.

HY2: The Corporate Governance component of Corporate Social Performance positively influences the Corporate Financial Performance of banks.

HY3: The Environmental component of Corporate Social Performance positively influences the Corporate Financial Performance of banks.

HY4: The Social component of Corporate Social Performance positively influences the Corporate Financial Performance of banks.

HY5: The Economic component of Corporate Social Performance positively influences the Corporate Financial Performance banks.

The first research hypothesis wants to test the impact of the CSP, measured through a global index of social performance, on the financial performance of banks. The following four research hypotheses decompose the global CSP index into its four components: Corporate Governance, Environmental, Economic and Social Performance.

\section{Methodology and Sample}

In line with the reference literature, the research hypotheses are verified through a panel data analysis. A Pooled model is performed first, supported by the results of the collinearity and heteroskedasticity tests, therefore, following the results of the Hausman tests, the use of an estimate with fixed effects or with random effects is defined.

The key independent variables are delayed by a period, in order to limit the problems of endogeneity and multicollinearity.

The econometric models used are:

(1) CFP $_{i t}=\alpha+\beta_{1}$ CSP $_{i t-1}+\beta_{2}$ Leverage $_{i t}+\beta_{3}$ NIM $_{i t}+\beta_{4}$ LoanDep $_{i t}+\beta_{5}$ CostInc $_{i t}+\beta_{6}$ Coverage $_{i t}+\beta_{7} \operatorname{lnTA}_{i t}$ $+\eta_{i}+\varepsilon_{i t}$

(2) CFP $_{i t}=\alpha+\beta_{1}$ CGOV $_{i t-1}+\beta_{2}$ Leverage $_{i t}+\beta_{3}$ NIM $_{i t}+\beta_{4}$ LoanDep $_{i t}+\beta_{5}$ CostInc $_{i t}+\beta_{6}$ Coverage $_{i t}+\beta_{7}$ $\ln T A_{i t}+\eta_{i}+\varepsilon_{i t}$ 
(3) CFP $_{i t}=\alpha+\beta_{1}$ ENVIR $_{i-1} \beta_{2}$ Leverage $_{i t}+\beta_{3}$ NIM $_{i t}+\beta_{4}$ LoanDep $_{i t}+\beta_{5}$ CostInc $_{i t}+\beta_{6}$ Coverage $_{i t}+\beta_{7}$ lnTA $_{i t}$ $+\eta_{i}+\varepsilon_{i t}$

(4) CFP $_{i t}=\alpha+\beta_{1}$ SOCIAL $_{i t-1}+\beta_{2}$ Leverage $_{i t}+\beta_{3}$ NIM $_{i t}+\beta_{4}$ LoanDep $_{i t}+\beta_{5}$ CostInc $_{i t}+\beta_{6}$ Coverage $_{i t}+\beta_{7}$ $\ln T A_{i t}+\eta_{i}+\varepsilon_{i t}$

(5) $C_{\text {CFP }}=\alpha+\beta_{1}$ ECON $_{i t-1}+\beta_{2}$ Leverage $_{i t}+\beta_{3}$ NIM $_{i t}+\beta_{4}$ LoanDep $_{i t}+\beta_{5}$ CostInc $_{i t}+\beta_{6}$ Coverage $_{i t}+\beta_{7}$ $\ln T A_{i t}+\eta_{i}+\varepsilon_{i t}$

\subsection{Variables}

In the present work for the CSP variable, five indices developed by Thomson Reuters - the Equal-weighted rating and the ratings determined by the company's performance in the four fundamental Economic, Environmental, Social and Corporate Governance areas - are used alternatively.

Corporate Governance rating affects the ability of a company to manage and control its rights and responsibilities through the creation of incentives and checks in order to generate long-term value for shareholders.

The Economic rating reflects the overall financial health of a company and its ability to generate long-term value for shareholders.

The Environmental rating considers the firm's ability to avoid environmental risks and exploit environmental opportunities in order to generate long-term value for shareholders.

Social rating measures a company's ability to capture the trust and loyalty of its workforce, customers and the social context. It is the result of the company's reputation.

The Corporate Financial Performance (CFP) is measured by the Return on Average Assets (ROAA) (Aupperle et al., 1985; Simpson \& Kohers, 2002; Van der Laan, Van Ees \& Van Witteloostuijn, 2008; Soana, 2011; Barnett \& Salomon, 2012), the Tobin's Q (Rose, 2007; Choi \& Wang, 2009), the Market Capitalization and the Return on Average Equity (ROAE).

The control variables refer to the assets and capital, liquidity and size of the banks.

The variables used for the analysis are shown in Table 1.

Table 1. Variables definitions

\begin{tabular}{lll}
\hline Notation & Description & Source \\
\hline $\begin{array}{l}\text { Corporate Financial Performance Variables } \\
\text { ROAA }\end{array}$ & (Net Income/Total Average Assets) x 100\% & Orbis \\
Tobin's Q & Market Capitalization/Total Assets & Orbis \\
lnMktCap & Logarithm (Number of shares x Closing price per share) & Orbis \\
ROAE & (Net Income/Average Shareholders' Equity) x 100\% & Orbis \\
Corporate Social Performance Variables & Thomson \\
lagCSP & Equal-Weighted Rating: determined by weighting performance across all four areas (Corporate & Reuters \\
& Governance, Economic, Environmental, Social) & Thomson \\
lagCGOV & Corporate Governance: measures a company's systems and processes, ensuring that management & Reuters \\
& acts in the interests of its long-term shareholders & Thomson \\
lagECON & Economic: measures the ability of a company to generate sustainable growth and a high return on & Reuters \\
& investment through the efficient use of all its resources & Thomson \\
lagENVIR & Environmental: measures the impact of a company on living and non-living natural systems & Reuters \\
& & Thomson \\
lagSOCIAL & Social: measures the ability of a company to generate trust and loyalty with its workforce, & Reuters \\
& customers and social capital & Orbis \\
Control variables & & Orbis \\
Leverage & Equity/ Liabilities & Orbis \\
NIM & Net Interest Income/Total Assets & Orbis \\
LoanDep & Net Loans/Deposits \& Short Term Found & Orbis \\
Coverage & Total Operating Expenses/ Total Operating Income & Orbis \\
lnTA & Loan loss reserves/Gross Loans & \\
\hline
\end{tabular}




\subsection{Sample}

The sample consists of 70 listed European banks (EU28), whose data refer to the period from 2011 to 2015 . The financial data are taken from the Orbis Bureau van Dijk database. The data referring to the five variables of Corporate Social Performance are taken from Thomson Reuters DataStream in the section ASSET4.

The descriptive statistics and the correlation analysis are provided in Tables 2 and 3.

The CSP is included between a minimum of $2.85 \%$ and a maximum of $96.57 \%$, with an average of about $63.53 \%$. The Corporate Governance variable is between a minimum of $1.24 \%$ and a maximum of $97.49 \%$ and has a mean of $52.26 \%$. The Environmental variable has a minimum of $8.59 \%$, a maximum of 95.08 and an average of $66.96 \%$. The Social variable has a minimum of $3.6 \%$, a maximum of $97.01 \%$ and an average of $67.41 \%$. Finally, the Economic variable has a minimum of $1.55 \%$, a maximum of $98.08 \%$ and an average of $58.47 \%$.

These values indicate a wide variability in the use of CSP and its components within the banks of the sample analyzed, however, the performance is a positive performance.

The descriptive statistics also indicate a wide variability for the market capitalization and ROAE.

Table 2. Descriptive statistics

\begin{tabular}{|c|c|c|c|c|c|}
\hline Variable & Obs & Mean & Std. Dev. & Min & Max \\
\hline CSP & 319 & 63.52661 & 32.17135 & 2.85 & 96.57 \\
\hline CGOV & 319 & 52.26223 & 28.49281 & 1.24 & 97.49 \\
\hline ENVIR & 319 & 66.95793 & 31.51205 & 8.59 & 95.08 \\
\hline SOCIAL & 319 & 67.41025 & 29.83385 & 3.6 & 97.01 \\
\hline ECON & 318 & 58.47025 & 30.82466 & 1.55 & 98.08 \\
\hline ROAA & 316 & 0.2323513 & 1.111271 & -6.832 & 3.415 \\
\hline Tobin's Q & 297 & 0.0721448 & .0690167 & 0.001 & 0.315 \\
\hline MktCap & 297 & 14459.44 & 17841.9 & 89.65328 & 104842.8 \\
\hline ROAE & 314 & 3.627611 & 15.04896 & -90.382 & 80.264 \\
\hline Leverage & 317 & 8.030767 & 4.496779 & -0.237 & 27.245 \\
\hline NIM & 317 & 1.998114 & 1.218464 & 0.078 & 7.366 \\
\hline LoanDep & 313 & 86.35779 & 22.68082 & 25.947 & 155.271 \\
\hline CostInc & 311 & 62.77394 & 15.7929 & 38.504 & 161.916 \\
\hline Coverage & 311 & 4.83474 & 4.020339 & 0.191 & 22.06 \\
\hline TA & 317 & $3.65 \mathrm{e}+08$ & $5.11 \mathrm{e}+08$ & 1171375 & $2.04 \mathrm{e}+09$ \\
\hline
\end{tabular}

Source: Processing of authors

Table 3. Correlation matrix

\begin{tabular}{|c|c|c|c|c|c|c|c|c|c|c|c|c|c|c|c|}
\hline & CSP & CGOV & ENVIR & SOCIAL & ECON & ROAA & TOBN'S Q & MKTCAP & ROAE & LEVERAGE & NIM & LOANDEP & COSTINC & COVERAGE & TA \\
\hline CSP & 1.000 & & & & & & & & & & & & & & \\
\hline CGOV & $0.805^{* * * *}$ & 1.000 & & & & & & & & & & & & & \\
\hline ENVIR & $0.922 * * *$ & $0.719^{* * *}$ & 1.000 & & & & & & & & & & & & \\
\hline SOCIAL & $0.940^{* * * *}$ & $0.6811^{* * *}$ & $0.865^{* * * *}$ & 1.000 & & & & & & & & & & & \\
\hline ECON & $0.801 * * *$ & $0.519^{* * *}$ & $0.593^{* * *}$ & $0.722 * * *$ & 1.000 & & & & & & & & & & \\
\hline ROAA & $-0.137 * *$ & $-0.196 * * *$ & $-0.279 * * *$ & $-0.145 * *$ & $0.158^{* * * *}$ & 1.000 & & & & & & & & & \\
\hline TOBIN'S Q & $-0.269^{* * * *}$ & $-0.340^{* * * *}$ & $-0.328 * * *$ & $-0.274 * * *$ & 0.026 & $0.596^{* * * *}$ & 1.000 & & & & & & & & \\
\hline MKTCAP & $0.503^{* * * *}$ & $0.593^{* * *}$ & $0.472^{* * * *}$ & $0.430^{* * * *}$ & $0.358^{* * *}$ & 0.006 & $-0.139 * *$ & 1.000 & & & & & & & \\
\hline ROAE & -0.058 & $-0.122^{* *}$ & $-0.153^{* * * *}$ & -0.091 & $0.151^{* * * *}$ & $0.778 * * *$ & $0.305^{* * * *}$ & 0.044 & 1.000 & & & & & & \\
\hline LEVERAGE & $-0.258 * * *$ & $-0.343 * * * *$ & $-0.305^{5 * * *}$ & $-0.243 * * *$ & -0.009 & $0.398 * * *$ & $0.799 * * *$ & $-0.218 * * *$ & $0.191 * * *$ & 1.000 & & & & & \\
\hline NIM & $-0.298 * * *$ & $-0.460^{* * * *}$ & $-0.312 * * *$ & $-0.256 * * *$ & $-0.103^{*}$ & $0.336^{* * *}$ & $0.538 * * *$ & $-0.252 * * *$ & $0.208^{* * * *}$ & $0.627^{* * * *}$ & 1.000 & & & & \\
\hline LOANDEP & $-0.106^{*}$ & -0.070 & $-0.132^{* *}$ & -0.078 & -0.053 & -0.030 & $-0.097^{*}$ & $-0.155^{* * * *}$ & -0.051 & -0.060 & -0.038 & 1.000 & & & \\
\hline COSTINC & $0.126^{* *}$ & $0.199 * * *$ & $0.174^{* * * *}$ & $0.105^{*}$ & -0.075 & $-0.449 * * *$ & $-0.436^{* * * *}$ & $0.173^{* * * *}$ & $-0.429^{* * * *}$ & $-0.283^{* * * *}$ & $-0.276^{* * *}$ & $-0.180^{* * * *}$ & 1.000 & & \\
\hline COVERAGE & -0.082 & $-0.142^{* * *}$ & 0.027 & -0.047 & $-0.205^{* * * *}$ & $-0.284 * * *$ & 0.000 & $-0.194 * * *$ & $-0.330^{* * * *}$ & $0.199 * * *$ & $0.289 * * *$ & -0.000 & 0.049 & 1.000 & \\
\hline TA & $0.511^{* * * *}$ & $0.600^{* * *}$ & $0.485 * * *$ & $0.460^{* * * *}$ & $0.321^{* * *}$ & -0.084 & $-0.358^{* * *}$ & $0.744^{* * * *}$ & -0.038 & $-0.373^{* * * *}$ & $-0.368^{* * * *}$ & $-0.302^{* * * *}$ & $0.230^{* * *}$ & $-0.241^{* * *}$ & 1.000 \\
\hline Significance: * & $0.10 ; * * \mathrm{p}<$ & $; * * * * \mathrm{p}<0.0$ & & & & & & & & & & & & & \\
\hline
\end{tabular}




\section{Results}

The results of the estimation of model (1) are shown in table 4, which shows only the results of the models chosen following the Hausman test; therefore, an estimate with robust fixed effects is used for the regression analyzes between CSP and ROAA, Tobin's Q and Market Capitalization, and an estimate with robust random effects for the CSP-ROAE relationship.

Table 4. Regression Analysis - eq. (1)

\begin{tabular}{|c|c|c|c|c|}
\hline & ROAA & Tobin's Q & lnMktCap & ROAE \\
\hline \multirow[t]{2}{*}{ Cost } & -6.762987 & $1.258766 * * *$ & -1.305127 & -0.0603057 \\
\hline & $(5.788705)$ & $(0.2937651)$ & $(4.62444)$ & $(17.72478)$ \\
\hline \multirow[t]{2}{*}{ LAGCSP } & $0.0142531 * * *$ & 0.000344 & $0.0063788 * * *$ & 0.0126257 \\
\hline & $(0.0052954)$ & $(0.0002187)$ & $(0.0021939)$ & $(0.0405727)$ \\
\hline \multirow[t]{2}{*}{ Leverage } & $0.1823606 * * *$ & $0.0079383 * * *$ & $0.1118038 * * *$ & $1.240989 * *$ \\
\hline & $(0.0349113)$ & $(0.0018713)$ & $(0.0248237)$ & $(0.5399097)$ \\
\hline \multirow[t]{2}{*}{ NIM } & $0.3827398 * * *$ & $0.0118452 * * *$ & $0.1328081 * * *$ & 0.9851498 \\
\hline & $(0.1044112)$ & $(0.0038289)$ & $(0.0462594)$ & $(1.162186)$ \\
\hline \multirow[t]{2}{*}{ LoanDep } & 0.0004257 & 0.0000435 & -0.0013789 & $-0.0641904 * *$ \\
\hline & $(0.0052115)$ & $(0.0003857)$ & $(0.0050477)$ & $(0.0312824)$ \\
\hline \multirow[t]{2}{*}{ CostInc } & -0.0136217 & -0.0002132 & -0.0027717 & $-0.3316478 * * *$ \\
\hline & $(0.008393)$ & $(0.0002451)$ & $(0.004506)$ & $(0.0967256)$ \\
\hline \multirow[t]{2}{*}{ Coverage } & $-0.0917291 *$ & $-0.0016085 *$ & 0.0167476 & $-1.516324 * * *$ \\
\hline & $(0.0498095)$ & $(0.0009119)$ & $(0.0300925)$ & $(0.2828534)$ \\
\hline \multirow[t]{2}{*}{ LNTA } & 0.2756706 & $-0.0679192 * * *$ & $0.4733931 *$ & 1.27608 \\
\hline & $(0.3297913)$ & $(0.0151119)$ & $(0.2402743)$ & $(1.022091)$ \\
\hline R2 Adj & 0.4039 & 0.4716 & 0.6804 & 0.4907 \\
\hline Observations & 216 & 212 & 213 & 215 \\
\hline F-test & 23.26 & 6.54 & 7.46 & 59.22 \\
\hline Model & Fixed Effect & Fixed Effect & Fixed Effect & Random Effects \\
\hline
\end{tabular}

Source: Processing of authors.

The results related to the Equal-Weighted Rating dependent variable show a positive and significant (1\%) relationship both with ROAA $\left(\beta_{1}=0.0142531\right)$ and with Market Capitalization $\left(\beta_{1}=0.0063788\right)$.

These results indicate that the CSR practices are associated with an increase in the average profitability of the banks' assets and an increase in market capitalization.

Table 5 summarizes the results of the model (2) related to the relationship between the Corporate Governance component and financial performance measures.

No significant relationship emerges between the Corporate Governance component and the financial performance measures of the banks. 
Table 5. Regression Analysis - eq. (2)

\begin{tabular}{lllll}
\hline & ROAA & Tobin's Q & lnMktCap & ROAE \\
\hline Cost & -7.292566 & $1.243269 * * *$ & -1.39578 & -2.965576 \\
LagCGOV & $(6.021352)$ & $(0.2913635)$ & $(4.555231)$ & $(18.95841)$ \\
& 0.0068342 & 0.0002001 & 0.0011297 & -0.0000247 \\
Leverage & $(0.0046029)$ & $(0.0001653)$ & $(0.0025996)$ & $(0.037404)$ \\
& $0.1929191 * * *$ & $0.0082254 * * *$ & $0.114473 * * *$ & $1.244717 * *$ \\
NIM & $(0.0389824)$ & $(0.0018877)$ & $(0.0249656)$ & $(0.5418579)$ \\
& $0.3679569 * * *$ & $0.0115801 * * *$ & $0.1216908 * *$ & 0.9924942 \\
LoanDep & $(0.108069)$ & $(0.0035585)$ & $(0.0532608)$ & $(1.185764)$ \\
& -0.0006755 & 0.000016 & -0.0017944 & $-0.0642281 * *$ \\
CostInc & $(0.0052993)$ & $(0.0003851)$ & $(0.0050697)$ & $(0.0314409)$ \\
& $-0.014967 *$ & -0.0002457 & -0.0032599 & $-0.3319156 * * *$ \\
Coverage & $(0.008131)$ & $(0.0002349)$ & $(0.0042646)$ & $(0.0954009)$ \\
& $-0.093014 *$ & $-0.0016667 *$ & 0.0180908 & $-1.514198 * * *$ \\
LnTA & $(0.0532021)$ & $(0.0009456)$ & $(0.0305387)$ & $(0.2822429)$ \\
& 0.3411018 & $-0.0662998 * * *$ & $0.5004906 * *$ & 1.472701 \\
R2 Adj & $(0.3422072)$ & $(0.0148634)$ & $(0.2343088)$ & $(1.024299)$ \\
Observations & 0.4970 & 0.4678 & 0.6395 & 0.4910 \\
F-Test & 216 & 212 & 213 & 215 \\
Model & 26.02 & 7.37 & 5.12 & 56.92 \\
Significance: $* \mathrm{p}<0.10 ; * * \mathrm{p}<0.05 ; * * * \mathrm{p}<0.01 ;$ the value of the error standard is shown in parentheses. & Random Effects \\
\hline
\end{tabular}

Source: Processing of authors.

Table 6 contains the results of the model (3).

Table 6. Regression Analysis - eq. (3)

\begin{tabular}{lllll}
\hline & ROAA & Tobin's Q & lnMktCap & ROAE \\
\hline Cost & -6.495854 & $1.262505 * * *$ & -1.212002 & -0.0244717 \\
LagENVIR & $(5.621335)$ & $(0.2930335)$ & $(4.735144)$ & $(17.82855)$ \\
& $0.0123269 *$ & 0.0001484 & 0.0043722 & 0.0132602 \\
Leverage & $(0.0063515)$ & $(0.0002629)$ & $(0.0026722)$ & $(0.0432066)$ \\
& $0.1846481 * * *$ & $0.0079693 * * *$ & $0.1129187 * * *$ & $1.244968 * *$ \\
NIM & $(0.0370958)$ & $(0.001788)$ & $(0.0241264)$ & $(0.5405928)$ \\
& $0.3721662 * * *$ & $0.0113322 * * *$ & $0.1262123 * *$ & 0.9905478 \\
LoanDep & $(0.1046072)$ & $(0.0035355)$ & $(0.0479508)$ & $(1.163316)$ \\
& 0.0003056 & 0.0000345 & -0.0014977 & $-0.0634364 * *$ \\
CostInc & $(0.0055139)$ & $(0.0003873)$ & $(0.0050834)$ & $(0.0309566)$ \\
& -0.0139754 & -0.000224 & -0.0029842 & $-0.3322127 * * *$ \\
Coverage & $(0.0084154)$ & $(0.0002391)$ & $(0.0043702)$ & $(0.0963068)$ \\
& $-0.0915249 *$ & -0.0014784 & 0.0173329 & $-1.529864 * * *$ \\
LnTA & $(0.0513987)$ & $(0.0009164)$ & $(0.028955)$ & $(0.2777178)$ \\
& 0.2682521 & $-0.0673679 * * *$ & $0.4761299 *$ & 1.27005 \\
R2 Adj & $(0.3299032)$ & $(0.0150568)$ & $(0.2475577)$ & $(1.029964)$ \\
Observations & 0.4197 & 0.4590 & 0.6539 & 0.4908 \\
F-Test & 216 & 212 & 213 & 215 \\
Model & 24.60 & 6.63 & 7.71 & 57.47 \\
Significance: $* \mathrm{p}<0.10 ; * * \mathrm{p}<$ & Fixed Effect & $0.05 ; * * * \mathrm{p}<0.01 ;$ the value of the error standard is shown in parentheses. & Random Effects \\
\hline Soure: Prof & & & \\
\hline
\end{tabular}

Source: Processing of authors.

The analysis related to the environmental component shows one significant and positive relationship with ROAA 
$\left(\beta_{1}=0.0123269\right)$.

The results of the model (4), which analyses the relationship between the Social component and the CFP measures, are in table 7 .

Table 7 - Regression Analysis - eq. (4)

\begin{tabular}{lllll}
\hline & ROAA & Tobin's Q & lnMktCap & ROAE \\
\hline Cost & -6.973864 & $1.254468 * * *$ & -1.338843 & -154.816 \\
LagSOCIAL & $(4.985575)$ & $(0.2933902)$ & $(4.747407)$ & $(113.1982)$ \\
& $0.0171889 * *$ & 0.0002726 & 0.0024699 & $0.2491638^{*}$ \\
Leverage & $(0.0069643)$ & $(0.0002668)$ & $(0.0025048)$ & $(0.131553)$ \\
& $0.1683433 * * *$ & $0.0077752 * * *$ & $0.1107843 * * *$ & $2.32414 * *$ \\
NIM & $(0.0300559)$ & $(0.0018531)$ & $(0.0240289)$ & $(1.018904)$ \\
& $0.3776608 * * *$ & $0.0115551 * * *$ & $0.1227396 * *$ & $3.191998 * *$ \\
LoanDep & $(0.1034002)$ & $(0.0036893)$ & $(0.0488214)$ & $(1.377922)$ \\
& 0.001499 & 0.0000509 & -0.0014761 & -0.0037353 \\
CostInc & $(0.0050715)$ & $(0.0003759)$ & $(0.0049792)$ & $(0.0788417)$ \\
& $-0.0136464 *$ & -0.0002246 & -0.0030615 & $-0.3262084 * *$ \\
Coverage & $(0.0073301)$ & $(0.0002306)$ & $(0.004268)$ & $(0.1542757)$ \\
& -0.0829474 & -0.0014813 & 0.019684 & -1.066742 \\
LnTA & $(0.0499221)$ & $(0.000921)$ & $(0.0300985)$ & $(0.9087891)$ \\
& 0.2725107 & $-0.067423 * * *$ & $0.490466 *$ & 7.501132 \\
R2 Adj & $(0.2782969)$ & $(0.015093)$ & $(0.2459466)$ & $(5.763113)$ \\
Observations & 0.3525 & 0.4634 & 0.6438 & 0.1773 \\
F-Test & 216 & 212 & 213 & 215 \\
Model & 20.56 & 6.64 & 5.87 & 4.03 \\
Significance: $* \mathrm{p}<0.10 ; * * \mathrm{p}<0.05 ; * * * \mathrm{p}<0.01 ;$ the value of the error standard is shown in parentheses. & Fixed Effect
\end{tabular}

Source: Processing of authors.

For the Social component, significant and positive relationships emerge with the ROAA $\left(\beta_{1}=0.0171889\right.$; significance at $5 \%)$ and with $\operatorname{ROAE}\left(\beta_{1}=0.2491638\right.$; significance at $\left.10 \%\right)$.

The results of the econometric model (5) are grouped in table 8 .

Table 8- Regression Analysis - eq. (5)

\begin{tabular}{|c|c|c|c|c|}
\hline & ROAA & Tobin's Q & lnMktCap & ROAE \\
\hline \multirow[t]{2}{*}{ Cost } & -6.856111 & $1.248365 * * *$ & -1.520505 & -5.269128 \\
\hline & $(5.783488)$ & $(0.3000655)$ & $(4.257105)$ & $(17.49524)$ \\
\hline \multirow[t]{2}{*}{ LagECON } & 0.0021474 & $0.0002608 * *$ & $0.0056931 * * *$ & -0.019646 \\
\hline & $(0.0026941)$ & $(0.0001236)$ & $(0.0016851)$ & $(0.0271667)$ \\
\hline \multirow[t]{2}{*}{ Leverage } & $0.1848159 * * *$ & $0.0079166 * * *$ & $0.1111033 * * *$ & $1.261612 * *$ \\
\hline & $(0.0365532)$ & $(0.0019479)$ & $(0.0246569)$ & $(0.5450357)$ \\
\hline \multirow[t]{2}{*}{ NIM } & $0.3538174 * * *$ & $0.0113417 * * *$ & $0.1237907 * * *$ & 1.037547 \\
\hline & $(0.1050921)$ & $(0.0037723)$ & $(0.0446411)$ & $(1.16081)$ \\
\hline \multirow[t]{2}{*}{ LoanDep } & -0.0004151 & 0.0000221 & -0.001789 & $-0.0634022 * *$ \\
\hline & $(0.005332)$ & $(0.0003878)$ & $(0.0050672)$ & $(0.0311408)$ \\
\hline \multirow[t]{2}{*}{ CostInc } & $-0.0143042 *$ & -0.0002033 & -0.0025087 & $-0.3357194 * * *$ \\
\hline & $(0.0082859)$ & $(0.0002457)$ & $(0.0043826)$ & $(0.0970534)$ \\
\hline \multirow[t]{2}{*}{ Coverage } & -0.0869457 & $-0.0015629 *$ & 0.0172747 & $-1.537425 * * *$ \\
\hline & $(0.0526819)$ & $(0.0009108)$ & $(0.0293247)$ & $(0.2909487)$ \\
\hline \multirow[t]{2}{*}{ LnTA } & 0.3302955 & $-0.0668856 * * *$ & $0.4909976 * *$ & $1.661133 *$ \\
\hline & $(0.3297593)$ & $(0.0152547)$ & $(0.2162801)$ & $(0.9172057)$ \\
\hline R2 Adj & 0.5480 & 0.4763 & 0.6672 & 0.4919 \\
\hline Observations & 216 & 212 & 213 & 215 \\
\hline F-Test & 25.18 & 6.40 & 6.87 & 61.30 \\
\hline Model & Fixed Effect & Fixed Effect & Fixed Effect & Random Effects \\
\hline
\end{tabular}

Source: Processing of authors. 
The model (5) shows a significant and positive relationship between the Economic component and Tobin's Q $\left(\beta_{1}=0.0002608\right)$ and a positive and significant relationship between the Economic component and Market capitalization $\left(\beta_{1}=0.0056931\right)$. No significant relationship emerges with the other two financial performance measures.

The economic component is positively associated with the prospective profitability of banks; therefore, it entails greater convenience in increasing investment spending and greater competitiveness. Moreover, the use of CSR practices seems to be rewarded by the financial market, producing a higher market capitalization.

Regression analyses show a consistent data trend between the various models. The $\mathrm{R}^{2}$ Adjusted have good values in all analyses carried out (between 0.4039 and 0.6872), except in the Model (4) related to the relationship between the Social variable the ROAA and the ROAE.

The data displayed show heterogeneity of results for the independent variables under consideration. On the contrary, the results related to the control variables are coherent among all the models. Leverage (Equity/liabilities) has positive and significant relationships with all dependent variables in all models $(1 \%$ with ROAA, Tobin's Q and Market capitalization; 5\% with ROAE). The Net Interest Margin has a positive and significant relationship (5\%) with ROAA, Tobin's Q, Market capitalization and ROAE, in models (1) and (4). Moreover, the Net Loans/Deposits and Short Term Found (LoanDep) shows a negative and significant (5\%) relationship with the ROAE in models (1), (2), (3) and (5). The cost to income ratio has negative relations with the ROAE. The coverage index has negative and significant relationships with the ROAE of the models (1), (2), (3) and (5), and negative and significant 10\% relation with the Tobin's Q (models (1), (2) and (5)) and with the ROAA (models (1), (2) and (3)). Finally, the logarithm of Total Assets has positive relationships (p-value $<0.1$ ) with Market capitalization in all analysis and negative (1\%) relationships with Tobin's $\mathrm{Q}$, in all models.

In summary, in line with the "Stakeholder theory" and with the findings of numerous authors (Simpson and Kohers, 2002; Wu and Shen, 2013; Forcadell and Aracil, 2017; Weber, 2017), we identify positive relationships between the global CSP component and the financial performance variables. Furthermore, there are significant relationships between the environmental component and the average profitability of assets, between the social component and financial performance of the banks and between the economic component of CSR and the performance of prospective profitability and Market capitalization.

The Corporate Governance component does not show any significant relationship with any of the financial performance measures used in the models of this study, in line with the results of Soana (2010) and the theory implemented by McWilliams and Siegel (2001).

Thus, these results lead to the rejection of the second research hypothesis but show that the remaining four research hypotheses are verified.

\section{Conclusions}

The work aims to test, according to the good management approach, the relationship between Corporate Social Performance (CSP) and Corporate Financial Performance (CFP) in the European banking industry.

The environmental component, the corporate governance component, the economic sustainability component, the social component, as well as the synthetic indicator of these four components, are related to different financial performance measures.

The empirical results show the more significant influence of the social component on the accounting measures of profitability, related to the profitability of equity (ROAE) and assets (ROAA). The social component measures a company's ability to capture the trust and loyalty of its workforce, customers and the social context. This component may be considered the result of the company's reputation; thus, the greater the reputation and the ability to capture and maintain trust and loyalty of the reference stakeholders, the greater the profitability of the bank's assets and equity. Thus, the social policies implemented by banks are aimed at increasing the level of trust and loyalty of employees, customers and society, and may determine greater returns in terms of profitability, in line with Wu and Shen (2013) and Dam and Scholtens (2015).

In addition, the economic sustainability component influences the Tobin's $\mathrm{Q}$ and the market capitalization. These results show that financial markets place considerable importance on CSR's economic activities, and reward the efficient use of resources to achieve sustainable economic growth. This response of the equity markets to CSR practices is consistent with the studies of Weber (2017) and Forcadell and Aracil (2017).

The Corporate Governance component does not affect banks' financial performance measures.

These results suggest investigating the existence of mechanisms of mediation between good governance policies 
and financial performance, such as the strategic monitoring and planning of the board (Post \& Byron, 2015).

Regarding the environmental component, only one positive association is found with the Return on average assets; there is no other significant relationship with other Corporate Financial Performance measures. This empirical result is in line with the reference literature that considers financial firms to have the least impact on the reference environmental systems (Vastola, Russo \& Vurro, 2017).

Finally, results related to the overall CSP measure, the social score and economic score indicator, confirm the good management approach postulated by the stakeholder theory, which assumes that with the consolidation of a series of relations with primary stakeholders, through ethical and social policies, the bank could increase its financial and economic performance (Freeman, 1984; Miles \& Covin, 2000).

These results can determine policy implications for bank managers, who should increase their commitment to social activities and policies, as well as to the economic sustainability of the intermediary, as this type of activities, useful for the creation of social capital, also produce positive financial returns. Moreover, the results suggest that bank managers may adopt CSR strategies as a strategic tool that enhances medium to long-term survival.

Finally, the regulator should encourage banks to reinforce their attention towards social and environmental policies to improve economic welfare, because banks use amounts of resources from stakeholders who expect the bank to undertake CSR activities in order to compensate for the use of their resources, by promoting sustainable development.

\section{References}

Achua, J. K. (2008). Corporate social responsibility in Nigerian banking system. Society and Business Review, 3(1), 57-71. https://doi.org/10.1108/17465680810852748

Aguilera, R. V., Williams, C. A., Conley, J. M., \& Rupp, D. E. (2006). Corporate governance and social responsibility: A comparative analysis of the UK and the US. Corporate Governance: An International Review, 14(3), 147-158. https://doi.org/10.1111/j.1467-8683.2006.00495.x

Aguinis, H., \& Glavas, A. (2012). What we know and don't know about corporate social responsibility: A review and research agenda. Journal of management, 38(4), 932-968. https://doi.org/10.1177\%2F0149206311436079

Ahamed, W. S. W., Almsafir, M. K., \& Al-Smadi, A. W. (2014). Does corporate social responsibility lead to improve in firm financial performance? Evidence from Malaysia. International Journal of Economics and Finance, 6(3), 126. https://doi.org/10.5539/ijef.v6n3p126

Alexander, G. J., \& Buchholz, R. A. (1978). Corporate social responsibility and stock market performance. Academy of Management journal, 21(3), 479-486. https://doi.org/10.5465/255728

Aupperle, K. E., Carroll, A. B., \& Hatfield, J. D. (1985). An empirical examination of the relationship between corporate social responsibility and profitability. Academy of Management Journal, 28(2), 446-463. https://doi.org/10.5465/256210

Babiak, K., \& Trendafilova, S. (2011). CSR and environmental responsibility: motives and pressures to adopt green management practices. Corporate Social Responsibility and Environmental Management, 18(1), 11-24. https://doi.org/10.1002/csr.229

Bacow, L. S. (1998). Risk sharing mechanisms for brownfields redevelopment. In Risk-Based Corrective Action and Brownfields Restorations, 178-195. https://doi.org/10.1061/9780784403891.012

Baranes, A. (2009). Towards sustainable and ethical finance. Development, 52(3), 416-420. https://doi.org/10.1057/dev.2009.47

Barnett, M. L. (2007). Stakeholder influence capacity and the variability of financial returns to corporate social responsibility. Academy of Management Review, 32(3), 794-816. https://doi.org/10.5465/amr.2007.25275520

Barnett, M. L., \& Salomon, R. M. (2006). Beyond dichotomy: The curvilinear relationship between social responsibility and financial performance. Strategic Management Journal, 27(11), 1101-1122. https://doi.org/10.1002/smj.557

Barnett, M. L., \& Salomon, R. M. (2012). Does it pay to be really good? Addressing the shape of the relationship between social and financial performance. Strategic Management Journal, 33(11), 1304-1320. https://doi.org/10.1002/smj.1980 
Beck, T., Demirgüç-Kunt, A., \& Levine, R. (2010). Financial institutions and markets across countries and over time: The updated financial development and structure database. The World Bank Economic Review, 24(1), 77-92. https://doi.org/10.1093/wber/lhp016

Berle Jr, A. A. (1930). Corporate powers as powers in trust. Harvard Law Review, 44(7), 1049-1074

Bhattacharya, C. B., \& Sen, S. (2004). Doing better at doing good: When, why, and how consumers respond to corporate social initiatives. California Management Review, 47(1), 9-24. https://doi.org/10.2307\%2F41166284

Billett, M. T., Flannery, M. J., \& Garfinkel, J. A. (1995). The effect of lender identity on a borrowing firm's equity return. The Journal of Finance, 50(2), 699-718. https://doi.org/10.1111/j.1540-6261.1995.tb04801.x

Birindelli, G., \& Tarabella, A. (2001). La responsabilità sociale delle imprese e $i$ nuovi strumenti di comunicazione nell'esperienza bancaria italiana, 61. Roma, IT: Franco Angeli.

Birindelli, G., Ferretti, P., Intonti, M., \& Iannuzzi, A. P. (2015). On the drivers of corporate social responsibility in banks: evidence from an ethical rating model. Journal of Management \& Governance, 19(2), 303-340. https://doi.org/10.1007/s10997-013-9262-9

Boulding, K. E. (1956). The image: Knowledge in life and society. University of Michigan Press.

Bowen, H. R. (1953). Social responsibilities of the businessman. New York, NY: Harper \& Row.

Brammer, S., \& Millington, A. (2008). Does it pay to be different? An analysis of the relationship between corporate social and financial performance. Strategic Management Journal, 29(12), 1325-1343. https://doi.org/10.1002/smj.714

Brammer, S., Agarwal, V., Taffler, R., \& Brown, M. (2015). Corporate Reputation and Financial Performance: The Interaction between Capability and Character. In European Financial Management Association. 2015 Annual Meeting: The Netherlands.

Branco, M. C., \& Rodrigues, L. L. (2006). Corporate social responsibility and resource-based perspectives. Journal of Business Ethics, 69(2), 111-132. https://doi.org/10.1007/s10551-006-9071-z

Bravo, R., Montaner, T., \& Pina, J. M. (2010). Corporate brand image in retail banking: development and validation of a scale. The Service Industries Journal, 30(8), 1199-1218. https://doi.org/10.1080/02642060802311260

Bushman, R. M., \& Wittenberg-Moerman, R. E. G. I. N. A. (2012). The role of bank reputation in "certifying" future performance implications of borrowers' accounting numbers. Journal of Accounting Research, 50(4), 883-930. https://doi.org/10.1111/j.1475-679X.2012.00455.x

Bussoli, C., \& Conte, D. (2018). The" Virtuous Circle" Between Corporate Social Performance and Corporate Financial Performance in the European Banking Sector. International Journal of Business Administration, 9(2), 80. https://doi.org/10.5430/ijba.v9n2p80

Callado-Muñoz, F. J., \& Utrero-González, N. (2011). Does it pay to be socially responsible? Evidence from Spain's retail banking sector. European Financial Management, 17(4), 755-787. https://doi.org/10.1111/j.1468-036X.2009.00518.x

Carnevale, C., \& Mazzuca, M. (2014). Sustainability report and bank valuation: evidence from European stock markets. Business Ethics: A European Review, 23(1), 69-90. https://doi.org/10.1111/beer.12038

Carroll, A. B. (1979). A three-dimensional conceptual model of corporate performance. Academy of management review, 4(4), 497-505. https://doi.org/10.5465/amr.1979.4498296

Carroll, A. B. (1998). The four faces of corporate citizenship. Business and society review, 100(1), 1-7. https://doi.org/10.1111/0045-3609.00008

Chemmanur, T. J., \& Fulghieri, P. (1994). Investment bank reputation, information production, and financial intermediation. The Journal of Finance, 49(1), 57-79. https://doi.org/10.1111/j.1540-6261.1994.tb04420.x

Chen, J. K., \& Chen, I. S. (2009). Corporate Reputation Measurement for the Privately Run Banking Industry in Taiwan. Global Journal of Business Research, 3(2), 65-75. https://ssrn.com/abstract=1629426

Chih, H. L., Chih, H. H., \& Chen, T. Y. (2010). On the determinants of corporate social responsibility: International evidence on the financial industry. Journal of Business Ethics, 93(1), 115-135. https://doi.org/10.1007/s10551-009-0186-x 
Choi, J., \& Wang, H. (2009). Stakeholder relations and the persistence of corporate financial performance. Strategic management journal, 30(8), 895-907. https://doi.org/10.1002/smj.759

Clarke, J., \& Gibson-Sweet, M. (1999). The use of corporate social disclosures in the management of reputation and legitimacy: a cross-sectoral analysis of UK Top 100 Companies. Business Ethics: A European Review, 8(1), 5-13. https://doi.org/10.1111/1467-8608.00120

Dam, L., \& Scholtens, B. (2015). Toward a theory of responsible investing: On the economic foundations of corporate social responsibility. Resource and Energy Economics, 41, 103-121. https://doi.org/10.1016/j.reseneeco.2015.04.008

Davis, K. (1960). Can business afford to ignore social responsibilities?. California management review, 2(3), 70-76. https://doi.org/10.2307\%2F41166246

Dorasamy, N. (2013). Corporate Social Responsibility and Ethical Banking for Developing Economies. Journal of Economics and Behavioral Studies, 5(11). 777-785. http://hdl.handle.net/10321/1151

Douglas, A., Doris, J., \& Johnson, B. (2004). Corporate social reporting in Irish financial institutions. The TQM Magazine, 16(6), 387-395. https://doi.org/10.1108/09544780410563301

Egede, T., \& Lee, R. (2007). Bank lending and the environment: not liability but responsibility. Journal of business law, (8), 868-883.

Elkington, J. (1997). Cannibals with forks - Triple bottom line of 21st century business. Stoney Creek, CT: New Society Publishers.

Esteban-Sanchez, P., de la Cuesta-Gonzalez, M., \& Paredes-Gazquez, J. D. (2017). Corporate social performance and its relation with corporate financial performance: International evidence in the banking industry. Journal of cleaner production, 162, 1102-1110. https://doi.org/10.1016/j.jclepro.2017.06.127

European Banking Federation, (2008) European banking sector best practices: Corporate Social Responsibility. EBF: Brussels. http://www.ebf-fbe.eu

Evangelinos, K. I., Skouloudis, A., Nikolaou, I. E., \& Leal Filho, W. (2009). An analysis of corporate social responsibility (CSR) and sustainability reporting assessment in the greek banking sector. In Professionals' Perspectives of Corporate Social Responsibility, 157-173. Heidelberg, Berlin: Springer.

Fatma, M., Rahman, Z., \& Khan, I. (2014). Multi-item stakeholder based scale to measure CSR in the banking industry. International Strategic Management Review, 2(1), 9-20. https://doi.org/10.1016/j.ism.2014.06.001

Fombrun, C., \& Shanley, M. (1990). What's in a name? Reputation building and corporate strategy. Academy of Management Journal, 33(2), 233-258. https://doi.org/10.5465/256324

Forcadell, F. J., \& Aracil, E. (2017). European Banks' reputation for corporate social responsibility. Corporate Social Responsibility and Environmental Management, 24(1), 1-14. https://doi.org/10.1002/csr.1402

Frederick, W. C. (1986). Toward CSR3: Why ethical analysis is indispensable and unavoidable in corporate affairs. California Management Review, 28(2), 126-141. https://doi.org/10.2307\%2F41165190

Frederick, W. C. (1994). From CSR1 to CSR2: The maturing of business-and-society thought. Business \& Society, 33(2), 150-164. https://doi.org/10.1177\%2F000765039403300202

Freedman, M., \& Jaggi, B. (1986). An analysis of the impact of corporate pollution disclosures included in annual financial statements on investors' decisions. Advances in public interest accounting, 1(2), 193-212.

Freeman, R. E. (1984). Strategic Management: A Stakeholder Approach. Boston, MA: Pitman.

Friedman, M. (1970). The social responsibility of business is to increase its profits. New York Times, 13, $122-126$

Garriga, E., \& Melé, D. (2004). Corporate social responsibility theories: Mapping the territory. Journal of business ethics, 53(1-2), 51-71. https://doi.org/10.1023/B:BUSI.0000039399.90587.34

Global Reporting Iniziative. (2008). Sustainability Reporting Guidelines. Financial Services Sector Supplement, GRI Amsterdam.

Godfrey, P. C., Merrill, C. B., \& Hansen, J. M. (2009). The relationship between corporate social responsibility and shareholder value: An empirical test of the risk management hypothesis. Strategic management journal, 30(4), 425-445. https://doi.org/10.1002/smj.750

Gompers, P. A., Ishii, J., \& Metrick, A. (2009). Extreme governance: An analysis of dual-class firms in the 
United States. The Review of Financial Studies, 23(3), 1051-1088. https://doi.org/10.1093/rfs/hhp024

Greenwood, J., \& Jovanovic, B. (1990). Financial development, growth, and the distribution of income. Journal of Political Economy, 98(5), 1076-1107. https://doi.org/10.1086/261720

Griffin, J. J., \& Mahon, J. F. (1997). The corporate social performance and corporate financial performance debate: Twenty-five years of incomparable research. Business \& Society, 36(1), 5-31. https://doi.org/10.1177\%2F000765039703600102

Hamid, F. Z. A. (2004). Corporate social disclosure by banks and finance companies: Malaysian evidence. Corporate Ownership and Control, 1(4), 118-130.

Herremans, I. M., Akathaporn, P., \& McInnes, M. (1993). An investigation of corporate social responsibility reputation and economic performance. Accounting, organizations and society, 18(7-8), 587-604. https://doi.org/10.1016/0361-3682(93)90044-7

Hossain, M., \& Reaz, M. (2007). The determinants and characteristics of voluntary disclosure by Indian banking companies. Corporate Social Responsibility and Environmental Management, 14(5), 274-288. https://doi.org/10.1002/csr.154

Hsu, K. T. (2012). The advertising effects of corporate social responsibility on corporate reputation and brand equity: Evidence from the life insurance industry in Taiwan. Journal of Business Ethics, 109(2), 189-201. https://doi.org/10.1007/s10551-011-1118-0

Hugenschmidt, H., Kermode, Y., Schumacher, I., \& Janssen, J. (1999). Sustainable Banking at UBS. Greener Management International, (27), 37-48. http://www.jstor.org/stable/greemanainte.27.37

Humphrey, J. E., Lee, D. D., \& Shen, Y. (2012). Does it cost to be sustainable?. Journal of Corporate Finance, 18(3), 626-639. https://doi.org/10.1016/j.jcorpfin.2012.03.002

Idowu, S. O., \& Leal Filho, W. (2009). Professionals' perspectives of corporate social responsibility. Springer, Berlin. https://doi.org/10.1007/978-3-642-02630-0

Iqbal, N., Ahmad, N., \& Kanwal, M. (2013). Impact of corporate social responsibility on profitability of Islamic and conventional financial institutions. Applied mathematics in Engineering, Management and Technology, $1(2), 26-37$.

Jamali, D. (2007). The case for strategic corporate social responsibility in developing countries. Business and Society Review, 112(1), 1-27. https://doi.org/10.1111/j.1467-8594.2007.00284.x

Jeucken, M., \& Bouma, J. (1999). The Changing Environment of Banks. Greener Management International, 27, 21-35.

Jo, H., \& Na, H. (2012). Does CSR reduce firm risk? Evidence from controversial industry sectors. Journal of business ethics, 110(4), 441-456. https://doi.org/10.1007/s10551-012-1492-2

King, R. G., \& Levine, R. (1993). Finance and growth: Schumpeter might be right. The quarterly journal of economics, 108(3), 717-737. https://doi.org/10.2307/2118406

Kolk, A., \& Pinkse, J. (2010). The integration of corporate governance in corporate social responsibility disclosures. Corporate Social Responsibility and Environmental Management, 17(1), 15-26. https://doi.org/10.1002/csr.196

Labatt, S., \& White, R. R. (2002). Environmental Finance, Hoboken, NJ: Wiley.

Landon, S., \& Smith, C. E. (1997). The use of quality and reputation indicators by consumers: the case of Bordeaux wine. Journal of Consumer Policy, 20(3), 289-323. https://doi.org/10.1023/A:1006830218392

Lantos, G. P. (2001). The boundaries of strategic corporate social responsibility. Journal of Consumer Marketing, 18(7), 595-632. https://doi.org/10.1108/07363760110410281

Lev, B., Petrovits, C., \& Radhakrishnan, S. (2010). Is doing good good for you? How corporate charitable contributions enhance revenue growth. Strategic Management Journal, 31(2), 182-200. https://doi.org/10.1002/smj.810

Levine, R. (2004). The corporate governance of banks: A concise discussion of concepts and evidence. The World Bank. https://doi.org/10.1596/1813-9450-3404

Lourenço, I. C., Callen, J. L., Branco, M. C., \& Curto, J. D. (2014). The value relevance of reputation for sustainability leadership. Journal of Business Ethics, 119(1), 17-28. 
https://doi.org/10.1007/s10551-012-1617-7

Manetti, G. (2011). The quality of stakeholder engagement in sustainability reporting: empirical evidence and critical points. Corporate Social Responsibility and Environmental Management, 18(2), 110-122. https://doi.org/10.1002/csr.255

Maon, F., Lindgreen, A., \& Swaen, V. (2010). Organizational stages and cultural phases: A critical review and a consolidative model of corporate social responsibility development. International Journal of Management Reviews, 12(1), 20-38. https://doi.org/10.1111/j.1468-2370.2009.00278.x

Margolis, J. D., \& Walsh, J. P. (2003). Misery loves companies: Rethinking social initiatives by business. Administrative science quarterly, 48(2), 268-305. https://doi.org/10.2307\%2F3556659

Matei, M., \& Voica, M. C. (2013). Social Responsibility in the Financial and Banking Sector. Economic Insights-Trends \& Challenges, 65(1), 115-123.

Matten, D. (2006). Why do companies engage in corporate social responsibility? Background, reasons and basic concepts. The ICCA handbook on corporate social responsibility, 3, 28.

McGuire, J. B., Sundgren, A., \& Schneeweis, T. (1988). Corporate social responsibility and firm financial performance. Academy of Management Journal, 31(4), 854-872. https://doi.org/10.5465/256342

McWilliams, A., \& Siegel, D. (2001). Corporate social responsibility: A theory of the firm perspective. Academy of management review, 26(1), 117-127. https://doi.org/10.5465/amr.2001.4011987

Milanzi, M. C. (1997). Business Ethics in Eastern and Southern Africa. Journal of Business Ethics, 16(14), 1549-1553. https://doi.org/10.1023/A:1005811014294

Miles, M. P., \& Covin, J. G. (2000). Environmental marketing: A source of reputational, competitive, and financial advantage. Journal of business ethics, 23(3), 299-311. https://doi.org/10.1023/A:1006214509281

Moon, J. (2007). The contribution of corporate social responsibility to sustainable development. Sustainable development, 15(5), 296-306. https://doi.org/10.1002/sd.346

Muller, A., \& Kräussl, R. (2011). Doing good deeds in times of need: A strategic perspective on corporate disaster donations. Strategic Management Journal, 32(9), 911-929. https://doi.org/10.1002/smj.917

Murray, M., \& Dainty, A. (Eds.). (2013). Corporate Social Responsibility in the Construction Industry. Abingdon, UK: Taylor \& Francis.

Newig, J., Schulz, D., Fischer, D., Hetze, K., Laws, N., Lüdecke, G., \& Rieckmann, M. (2013). Communication regarding sustainability: Conceptual perspectives and exploration of societal subsystems. Sustainability, 5(7), 2976-2990. https://dx.doi.org/10.3390/su5072976

Ofori, D. F., S-Darko, M. D., \& Nyuur, R. B. (2014). Corporate social responsibility and financial performance: Fact or fiction? A look at Ghanaian banks. Acta Commercii, 14(1), 1-11. https://doi.org/10.4102/ac.v14i1.180

Oh, W. Y., Chang, Y. K., \& Martynov, A. (2011). The effect of ownership structure on corporate social responsibility: Empirical evidence from Korea. Journal of Business Ethics, 104(2), 283-297. https://doi.org/10.1007/s10551-011-0912-z

Orlitzky, M., \& Benjamin, J. D. (2001). Corporate social performance and firm risk: A meta-analytic review. Business \& Society, 40(4), 369-396. https://doi.org/10.1177\%2F000765030104000402

Orlitzky, M., \& Swanson, D. L. (2012). Assessing stakeholder satisfaction: Toward a supplemental measure of corporate social performance as reputation. Corporate Reputation Review, 15(2), 119-137. https://doi.org/10.1057/crr.2012.3

Orlitzky, M., Schmidt, F. L., \& Rynes, S. L. (2003). Corporate social and financial performance: A meta-analysis. Organization studies, 24(3), 403-441. https://doi.org/10.1177/0170840603024003910

Pérez, A., \& Del Bosque, I. R. (2013). How customer support for corporate social responsibility influences the image of companies: Evidence from the banking industry. Corporate Social Responsibility and Environmental Management, 22(3), 155-168. https://doi.org/10.1002/csr.1331

Podolny, J. M. (1993). A status-based model of market competition. American Journal of Sociology, 98(4), 829-872. https://doi.org/10.1086/230091

Polychronidou, P., Ioannidou, E., Kipouros, A., Tsourgiannis, L., \& Simet, G. F. (2014). Corporate social 
responsibility in Greek banking sector-An empirical research. Procedia Economics and Finance, 9, 193-199. https://doi.org/10.1016/S2212-5671(14)00020-3

Porter, M. E., \& Van der Linde, C. (1995). Toward a new conception of the environment-competitiveness relationship. Journal of economic perspectives, 9(4), 97-118. https://doi.org/10.1257/jep.9.4.97

Porter, M., \& Kramer, M. (2006). Estrategia y sociedad. Harvard business review, 84(12), 42-56.

Post, C., \& Byron, K. (2015). Women on boards and firm financial performance: A meta-analysis. Academy of Management Journal, 58(5), 1546-1571. https://doi.org/10.5465/amj.2013.0319

Revathy, B. (2012). Corporate social responsibility-an implementation guide for business. Far East Journal of Psychology and Business, 6(2), 15-31.

Rose, C. (2007). Does female board representation influence firm performance? The Danish evidence. Corporate Governance: An International Review, 15(2), 404-413. https://doi.org/10.1111/j.1467-8683.2007.00570.x

Ross, D. G. (2010). The "dominant bank effect:" How high lender reputation affects the information content and terms of bank loans. The Review of Financial Studies, 23(7), 2730-2756. https://doi.org/10.1093/rfs/hhp117

Sakarya, S., Bodur, M., Yildirim-Öktem, Ö., \& Selekler-Göksen, N. (2012). Social alliances: Business and social enterprise collaboration for social transformation. Journal of Business Research, 65(12), 1710-1720. https://doi.org/10.1016/j.jbusres.2012.02.012

Saxena, M., \& Kohli, A. S. (2012). Impact of Corporate Social Responsibility on Corporate Sustainability: A Study of the Indian Banking Industry. IUP Journal of Corporate Governance, 11(4), 39-54.

Scheire, C., \& De Maertelaere, S. (2009). Banking to make a difference. A preliminary research paper on the business models of the founding member banks of the Global Alliance for Banking on Values. Artevelde University College Gent.

Schmidheiny, S., \& Zorraquín, F. (1996). Financing Change: The Financial Community. Ecoefficiency, and Sustainable Development. Cambridge, UK: Mass.

Scholtens, B. (2008). A note on the interaction between corporate social responsibility and financial performance. Ecological economics, 68(1-2), 46-55. https://doi.org/10.1016/j.ecolecon.2008.01.024

Scholtens, B. (2009). Corporate social responsibility in the international banking industry. Journal of Business Ethics, 86(2), 159-175. https://doi.org/10.1007/s10551-008-9841-x

Scholtens, B., \& Dam, L. (2007). Banking on the Equator. Are banks that adopted the Equator Principles different from non-adopters?. World Development, 35(8), 1307-1328. https://doi.org/10.1016/j.worlddev.2006.10.013

Semenova, N., \& Hassel, L. G. (2015). On the validity of environmental performance metrics. Journal of Business Ethics, 132(2), 249-258. https://doi.org/10.1007/s10551-014-2323-4

Shen, C. H., \& Lee, C. C. (2006). Same financial development yet different economic growth: why?. Journal of Money, Credit and Banking, 38(7), 1907-1944. https://www.jstor.org/stable/3838970

Shen, C. H., Wu, M. W., Chen, T. H., \& Fang, H. (2016). To engage or not to engage in corporate social responsibility: Empirical evidence from global banking sector. Economic Modelling, 55, 207-225. https://doi.org/10.1016/j.econmod.2016.02.007

Simpson, W. G., \& Kohers, T. (2002). The link between corporate social and financial performance: Evidence from the banking industry. Journal of business ethics, 35(2), 97-109. https://doi.org/10.1023/A:1013082525900

Smurthwaite, M. (2014). Business ethics as field of training, teaching and research in Southern Africa. African Journal of Business Ethics, 5(2). http://dx.doi.org/10.15249/5-2-55

Soana, M. G. (2011). The relationship between corporate social performance and corporate financial performance in the banking sector. Journal of Business Ethics, 104(1), 133. https://doi.org/10.1007/s10551-011-0894-x

Stubbs, W., \& Cocklin, C. (2008). Conceptualizing a "sustainability business model". Organization \& Environment, 21(2), 103-127. https://doi.org/10.1177\%2F1086026608318042

Surroca, J., Tribó, J. A., \& Waddock, S. (2010). Corporate responsibility and financial performance: The role of intangible resources. Strategic Management Journal, 31(5), 463-490. https://doi.org/10.1002/smj.820 
Thompson, P., \& Cowton, C. J. (2004). Bringing the environment into bank lending: implications for environmental reporting. The British Accounting Review, 36(2), 197-218. https://doi.org/10.1016/j.bar.2003.11.005

Ullmann, A. A. (1985). Data in search of a theory: A critical examination of the relationships among social performance, social disclosure, and economic performance of US firms. Academy of management review, 10(3), 540-557. https://doi.org/10.5465/amr.1985.4278989

Van Beurden, P., \& Gössling, T. (2008). The worth of values-a literature review on the relation between corporate social and financial performance. Journal of business ethics, 82(2), 407. https://doi.org/10.1007/s10551-008-9894-X

Van der Laan, G., Van Ees, H., \& Van Witteloostuijn, A. (2008). Corporate social and financial performance: An extended stakeholder theory, and empirical test with accounting measures. Journal of Business Ethics, 79(3), 299-310. https://doi.org/10.1007/s10551-007-9398-0

Van Heerden, \& C. H., Puth, G. (1995). Factors that determine the corporate image of South African banking institutions: an exploratory investigation. International Journal of Bank Marketing, 13(3), 12-17, https://doi.org/10.1108/02652329510082979

Vastola, V., Russo, A., \& Vurro, C. (2017). Dealing with cultural differences in environmental management: Exploring the CEP-CFP relationship. Ecological Economics, 134, 267-275. https://doi.org/10.1016/j.ecolecon.2016.11.006

Viganò, F., \& Nicolai, D. (2009). CSR in the European banking sector: evidence from a survey. In Corporate Social Responsibility in Europe. Northampton, UK: E. Elgar.

Waddock, S. A., \& Graves, S. B. (1997). The corporate social performance-financial performance link. Strategic $\begin{array}{llll}\text { management } & \text { journal, } & \text { 303-319. }\end{array}$ https://doi.org/10.1002/(SICI)1097-0266(199704)18:4\%3C303::AID-SMJ869\%3E3.0.CO;2-G

Walls, J. L., Berrone, P., \& Phan, P. H. (2012). Corporate governance and environmental performance: Is there really a link?. Strategic Management Journal, 33(8), 885-913. https://doi.org/10.1002/smj.1952

Walsh, G., Bartikowski, B., \& Beatty, S. E. (2014). Impact of customer-based corporate reputation on non-monetary and monetary outcomes: The roles of commitment and service context risk. British Journal of Management, 25(2), 166-185. https://doi.org/10.1111/j.1467-8551.2012.00845.x

Wang, H., Choi, J., \& Li, J. (2008). Too little or too much? Untangling the relationship between corporate philanthropy and firm financial performance. Organization Science, 19(1), 143-159. https://doi.org/10.1287/orsc.1070.0271

Wang, Q., Dou, J., \& Jia, S. (2016). A meta-analytic review of corporate social responsibility and corporate financial performance: The moderating effect of contextual factors. Business \& Society, 55(8), 1083-1121. https://doi.org/10.1177/0007650315584317

Wartick, S. L., \& Cochran, P. L. (1985). The evolution of the corporate social performance model. Academy of management review, 10(4), 758-769. https://doi.org/10.5465/amr.1985.4279099

Weber, O. (2005). Sustainability benchmarking of European banks and financial service organizations. Corporate Social Responsibility and Environmental Management, 12(2), 73-87. https://doi.org/10.1002/csr.77

Weber, O. (2012). Environmental credit risk management in banks and financial service institutions. Business Strategy and the Environment, 21(4), 248-263. https://doi.org/10.1002/bse.737

Weber, O., Diaz, M., \& Schwegler, R. (2014). Corporate social responsibility of the financial sector-Strengths, weaknesses and the impact on sustainable development. Sustainable Development, 22(5), 321-335. https://doi.org/10.1002/sd.1543

Weber, O., Fenchel, M., \& Scholz, R. W. (2008). Empirical analysis of the integration of environmental risks into the credit risk management process of European banks. Business Strategy and the Environment, 17(3), 149-159. https://doi.org/10.1002/bse.507

Weshah, S. R., Dahiyat, A. A., Awwad, M. R. A., \& Hajjat, E. S. (2012). The impact of adopting corporate social responsibility on corporate financial performance: Evidence from Jordanian banks. Interdisciplinary Journal of Contemporary Research in Business, 4(5), 34-44. 
Wood, D. J. (1991). Corporate social performance revisited. Academy of management review, 16(4), 691-718. https://doi.org/10.5465/amr.1991.4279616

Wood, D. J., \& Jones, R. E. (1995). Stakeholder mismatching: a theoretical problem in empirical research on corporate social performance. The International Journal of Organizational Analysis, 3(3), 229-267. https://doi.org/10.1108/eb028831

Wu, M. W., \& Shen, C. H. (2013). Corporate social responsibility in the banking industry: Motives and financial

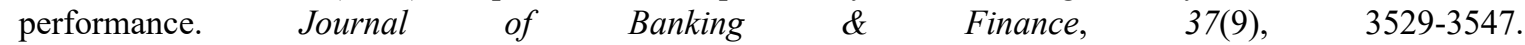
https://doi.org/10.1016/j.jbankfin.2013.04.023

Yen, T. T. H. (2014). CRS in banking sector. A literature review and new research directions, International Journal of Economics, Commerce and Management United Kingdom, 2(11), 1-22. http://dl.ueb.vnu.edu.vn/handle/1247/9937

\section{Copyrights}

Copyright for this article is retained by the author(s), with first publication rights granted to the journal.

This is an open-access article distributed under the terms and conditions of the Creative Commons Attribution license (http://creativecommons.org/licenses/by/4.0/). 